\title{
$\underline{\text { O infanticídio: um crime excepcional }}$
}

Fabíola Rohden

\section{SciELO Books / SciELO Livros / SciELO Libros}

ROHDEN, F. O infanticídio: um crime excepcional. In.: A arte de enganar a natureza: contracepção, aborto e infanticídio no início do século XX [online]. Rio de Janeiro: Editora FIOCRUZ, 2003, pp. 155-177. História e saúde collection. ISBN: 978-65-5708-117-4. https://doi.org/10.7476/9786557081174.0007.

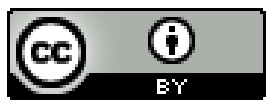

All the contents of this work, except where otherwise noted, is licensed under a Creative Commons Attribution 4.0 International license.

Todo o conteúdo deste trabalho, exceto quando houver ressalva, é publicado sob a licença Creative Commons Atribição 4.0.

Todo el contenido de esta obra, excepto donde se indique lo contrario, está bajo licencia de la licencia Creative Commons Reconocimento 4.0. 


\section{O Infanticídio: \\ um crime excepcional}

Um tipo de crime, em especial, parecia provocar os maiores debates em torno de uma suposta propensão feminina à maternidade. Trata-se do infanticídio, freqüentemente descrito pelos agentes da lei como o mais perverso comportamento possível para uma mulher. O tema aparecia de forma bastante complexa, provocando diversos debates jurídicos, mas tendo sempre como uma constante a referência à hipótese da privação dos sentidos e da inteligência no momento do crime - uma tese bastante recorrente na época.

O primeiro caso encontrado ocorreu em 1907. Envolvia Delmira Maria da Conceição, uma moça de 18 anos, solteira, que foi denunciada pela patroa. A dona da casa em que trabalhava encontrou manchas de sangue no assoalho logo constatou que eram devidas ao parto de Delmira. Segundo a conclusão do delegado, Delmira

não se limitara ao abandono do filho deixando-o perecer pela não prestação dos cuidados necessários à conservação da vida; fora muito além, e, sacudindo-o no caixão de lixo concorrera positivamente para a morte do recém-nascido, cuja a causa segundo o parecer dos médicos legistas foi asfixia por sufocação.

O seu namorado, um operário de 21 anos, disse à polícia que Delmira tinha vergonha de estar grávida ainda solteira e por isso quisera tomar remédios para abortar, o que ele desaconselhara, explicando a ela que a provocação do aborto era um crime. Ao mesmo tempo, o rapaz também confirmou o depoimento dela, negando que o aborto tivera sido provocado. Segundo a própria Delmira, ela sentira um forte susto e fora até a "reservada", onde abortara. A criança teria nascido morta e fora jogada no lixo. Nota-se 
que há uma confusão entre parto e aborto. Porém, o delegado resolveu enquadrar o crime cometido como infanticídio e enviou ao juiz um pedido de prisão preventiva da acusada. ${ }^{1}$ Esse enredo iria se repetir em outro processo, bastante rico em detalhes e que permite uma análise bem mais demorada.

\section{O Caso Gloria}

Trata-se de um processo movido em 1908 contra Gloria Lourenço da Silva. ${ }^{2}$ Gloria era uma moça portuguesa, solteira, analfabeta, com 27 anos. Deparei-me com uma dramática parte de sua trajetória de vida em consulta a um inquérito aberto em 31 de julho de 1908, quando foi encontrada a cabeça de uma criança no pátio interno da Biblioteca da Faculdade de Medicina do Rio de Janeiro. ${ }^{3}$

No documento, o delegado responsável pelo caso descreveu os acontecimentos envolvendo Gloria. Contou como fora chamado até o local, encontrara a peça mencionada e mandara fazer o exame médico-legal, iniciando as investigações. Não demorara muito para descobrir que, no sobrado que ficava ao lado da Biblioteca, morava uma moça que as vizinhas suspeitavam que estivesse grávida. O delegado fora até a casa de Gloria, encontrara manchas de sangue pelo chão e em algumas roupas e solicitara uma equipe para o desentupimento da latrina que ficava no sótão do sobrado. Lá, foram encontrados o tronco e os membros do feto, que também foram remetidos para exame.

A perícia fora chamada para fazer o seu trabalho. Examinaram-se também a faca e a saia manchadas de sangue, além das marcas de sangue encontradas no terraço da casa. O processo continha até mesmo croquis da casa e do terraço. Mas o mais curioso eram os decalques das manchas de sangue encontradas no chão e uma experiência feita com um gato. Uma possibilidade aventada foi a de que um gato teria transportado a cabeça da criança até o pátio da Biblioteca e, portanto, as manchas de sangue no chão teriam sido deixadas por esse animal. Os peritos fizeram ensaios utilizando um gato com as patas manchadas de tinta e eliminaram a hipótese. Mas as peças mais chocantes do processo eram as fotografias, ainda em excelente estado, da cabeça e do corpo da criança nos respectivos locais onde foram encontrados.

Ainda no dia 31 de julho a acusada depôs pela primeira vez, negando que tivesse realizado um infanticídio e mesmo que estivesse grávida. 
O irmão de Gloria, José Lourenço da Silva, disse que naquele dia a irmã não fora trabalhar no mercado, como de costume, e ficara trancada no quarto dizendo que estava passando mal. Ele não notara nada de anormal $e$ ficara surpreso com a presença da polícia. Acrescentou que não suspeitava que Gloria estivesse grávida, pois acreditava que ela ainda era virgem.

Gloria insistiu que era virgem. O delegado, então, fez com que ela fosse examinada pelos legistas, que comprovaram o parto recente. Em um novo depoimento, ela mudou sua versão e contou outra história. Disse que namorava um homem, ainda em Portugal, com quem tivera relações sexuais e de quem engravidara. Mantivera o fato em segredo. No dia 30 de julho tinha se sentido muito mal e resolvera ficar no seu quarto. Sentia muitas dores na barriga e dirigira-se à latrina. Lá, dera à luz uma menina que caíra diretamente dentro do vaso. Com as mãos, Gloria retirara a criança de dentro da latrina, envolvendo-a em um avental. Fora até a cozinha em busca de uma faca para cortar o cordão umbilical. Percebera então que a criança tinha nascido morta. Voltara à latrina e lá jogara a placenta e o corpo da criança. Como a cabeça não passava, decepara-a.

O exame médico-legal feito no corpo da criança atestou que ela ainda estava com vida quando nascera e fora esquartejada. O delegado então acusou Gloria de infanticídio com base no seu relato e na autópsia, e pediu a prisão preventiva, que foi decretada. Em 10 de agosto ela depôs novamente, já na enfermaria da Casa de Detenção. Repetiu o que disse anteriormente. Pela riqueza de detalhes com que descreveu o andamento das investigações e também pela utilização dos argumentos de condenação, o delegado encerrou as investigações com uma acusação singular. Transcrevo integralmente esta parte do processo, que, apesar de longa, é bastante valiosa:

Na manhã de 31 de julho passado findo, foi o espírito público abalado com a notícia assaz impressionadora de que mais um crime misterioso houvera sido perpetrado, dessa vez, contra um inocente recém-nascido, vítima, conforme se verificou mais tarde, dos sentimentos bestiais de quem tinha o dever de ampará-lo no mundo. Eram onze horas da manhã quando esta Delegacia teve ciência pelo guarda civil n. 627, de que no pátio interno do edifício em que funcionava a Biblioteca da Faculdade de Medicina fora encontrada a cabeça de uma criança recémnascida, ainda tinta de sangue. Partindo para o local, com a presteza que o caso exigia, ali iniciei rigorosas investigações, (...) e procedo a diligências urgentes, como fossem: exame de descrição de local, cuja fotografia 
se acha (...), e auto de encontro da referida cabeça, que em seguida fiz remeter ao Necrotério, para os fins legais. Prosseguindo nas pesquisas, foi a nossa atenção despertada para a parte posterior do sobrado número 12 do Beco da Batalha, e ali conseguido o acesso, notamos, à primeira inspeção, no sótão do mesmo prédio, pequenas manchas no soalho, manchas que se tornaram algo suspeitas. A respeito inqueri ligeiramente os moradores presentes, recaindo as minhas desconfianças na pessoa de Gloria Lourenço da Silva, residente no aludido sótão, em companhia de dois irmãos, José e Antonio Lourenço da Silva, e de dois outros indivíduos, que também foram por mim ouvidos. E essas desconfianças se acentuaram quando verifiquei a existência de manchas de sangue no aposento de Gloria, em sua cama, no muro de uma pequena área e, principalmente, no aparelho sanitário, que me pareceu se achar obstruído. Seguro do êxito das diligências, requisitei a presença de trabalhadores da 'City Improvements', para o fim que se fazia indispensável: - a desobstrução do mencionado aparelho. Tal diligência produziu, como eu esperava, bom resultado, sendo retirado da sentina o tronco de uma criança barbaramente mutilado.

Lavrado o competente auto, solicitou-se o comparecimento de um fotógrafo e fez-se remessa dos despojos da vítima para o Necrotério, tendo sido requisitado exame de autópsia. Requisitei também exame em uma saia pertencente à Gloria que se achava no aposento desta, apresentando manchas de sangue, e em três facas comuns, apreendidas na cozinha da casa. Por se fazer necessária, ordenei a condução de Gloria e demais moradores do sótão aludido para esta Delegacia, onde os submeti à severa inquirição.

Como se vê (...), Gloria - aparentando extraordinária fortaleza de ânimo 4 e sacrificando por completo a verdade - negou ter sido a autora de tão monstruoso atentado. Escusando-se na sua honra, fundamente atacada, invocava ora o seu passado de mulher honesta que vivia em companhia de seus irmãos, ora atribuía as manchas de sangue encontradas em sua cama e em suas vestes a incômodos catameniais. Gloria mentia, mentia cinicamente.

Para melhor armar ao efeito, Gloria pedia que a mandassem examinar, pois desejava provar ser ainda virgem. Foi atendida, mesmo porque tal prova era indispensável ao descobrimento completo da verdade. $\mathrm{E}(. .$.$) , puderam os médicos legistas assegurar que efetivamente Gloria$ houvera recentemente dado à luz uma criança e que o seu estado de saúde reclamava imediato tratamento.

Reinquerida, Gloria - que já estava ciente do resultado do exame a que se submetera - compreendeu então que tudo estava descoberto, que, portanto, inútil seria qualquer insistência em negar; e, assim, com uma 
precisão pasmosa, reconstruiu o seu crime, calma e friamente, apresentando ao mundo o tipo de uma mãe que impiedosamente estrangula e retalha o corpo do seu próprio filho.

Bem dolorosa deveria ter sido para Gloria essa hora de provação, em que, desvendando o seu crime, se lembrava daquela que lhe dera o ser e que tivera um procedimento bem diferente do seu, e em que compreende a hediondez de seu crime, vendo-se repudiada pelos seus próprios irmãos.

Do exame de autópsia (...), verifica-se que a criança (...) chegou ao termo de sua evolução e teve vida extra-uterina, sendo a sua morte produzida por decaptação e esquartejamento.

Em face da prova indiciária e da (...) confissão livre, clara e minuciosa, com todos os requisitos da prova, exigidos pelos criminalistas, representei ao Meritíssimo Doutor Juiz da $4^{a}$ Pretoria, no sentido de ser concedido o mandado de prisão preventiva contra Gloria Lourenço da Silva (...), que em luminoso e jurídico despacho julgou procedente o pedido e decretou a prisão preventiva da indiciada, pelo crime previsto no Art. 298, Parágrafo único [referente ao crime de infanticídio], do Código Penal. (...) Rio, 10 de agosto de 1908. Fábio Rino Junior.

O que se destaca no documento é a referência ao ato brutal cometido pela mãe. O delegado enfatizou que o crime fora cometido por quem tinha a obrigação de amparar a criança. A ré foi apresentada como "o tipo de mãe que impiedosamente estrangula e retalha o corpo do seu próprio filho". E o pior é que ela foi capaz de descrever todo o processo cuidadosamente, com uma "precisão pasmosa". Antes de fazê-lo, também tinha tido frieza suficiente para invocar sua honra e honestidade e "mentir cinicamente". $O$ argumento central foi que ela cometera o crime e o fizera com plena consciência, o que seria provado pela frieza apresentada por Gloria e pela narração detalhada que fez do evento. E a natureza brutal do crime foi descrita a partir do fato de ser a própria mãe a autora, aquela que naturalmente deveria amar e cuidar do recém-nascido em qualquer circunstância. É preciso dizer que o delegado não mencionou o motivo do crime, o que deixa o ato cometido por Gloria no terreno do completo absurdo, e não serviu senão para enfatizar seu caráter hediondo.

A partir da acusação formulada pelo delegado, o processo continuou seu andamento. Gloria passou a ter um advogado, Gastão Pictoria, que em 4 de setembro apresentou um atestado comprovando a sua boa índole com a declaração de testemunhas. No dia 8 de setembro, o advogado 
apresentou, por escrito, a defesa de sua cliente. Na primeira parte desse documento, Gastão Pictoria se dedicou a criticar os procedimentos do processo e em especial a denúncia elaborada pelo Ministério Público: ${ }^{5}$

A atitude calma, refletida e imparcial do íntegro e ilustrado juiz instrutor deste processo, durante a respectiva formação da culpa, permitiu que no decorrer da instrução criminal ficasse evidentíssima a situação da acusada, que agora surge aos olhos de todos, 'não como uma mãe desnaturada', uma 'terrível delinqüente', ou ainda 'uma crudelíssima e inaudita infanticida'. E também ficou apurado, que a acusada não 'agiu com uma ferocidade inaudita', como desembaraçada e impropriamente qualificou o digno órgão da justiça pública (...). Devemos mesmo assinalar, em que isso pese ao digno prolator da denúncia (...) que S. S. exorbitou das funções, que digna e brilhantemente exerce, 'usando de qualificativo e demais adjetivos que se encontram na denúncia (...) relativamente à acusada'. No estado atual, do nosso processo criminal, a denúncia, principalmente quando oferecida pelo Ministério Público, é um documento em que o denunciante se deve limitar à 'narração do fato delituoso com todas as circunstâncias', além das demais formalidades (...). (Grifos do autor)

Segundo o advogado, a idéia da mãe desnaturada, evocada na denúncia, teria sido refutada. Pictoria continua seu trabalho, também desqualificando a perícia:

O laudo pericial, vacilante, na impossibilidade de tirar uma conclusão positiva 'nem dizer que a morte do recém-nascido deu-se por meio violento, indicando que esse meio violento foi a decapitação e o esquartejamento'. Ora, essa conclusão absurda não pode constituir prova de infanticídio, porque não é admissível, não entra na esfera das causas humanas que possa ter lugar a morte de qualquer ente, ao mesmo tempo por decapitação e esquartejamento.

A vida extra-uterina do feto também não está positivamente determinada, e quando o estivesse, isso não seria um indício veemente do infanticídio, pois a morte do feto poder-se-ia ter dado naturalmente logo após o parto dadas as condições em que o mesmo teve lugar, sem os mínimos cuidados indispensáveis a uma parturiente e a assistência do recém-nascido.

É ainda evidente, que o laudo pericial não afirmou, como o deveria ter feito e o aconselham todos os tratadistas de medicina judiciária, que os fragmentos do corpo esquartejado apresentassem os vestígios característicos de terem sido cortados de um corpo ainda com vida, ou se de um cadáver. O mesmo se deu com a cabeça do feto, pois os peritos não 
afirmam que a mesma apresente os sinais característicos de ter sido cortada de corpo com vida, ou se de um cadáver.

Essa distinção capital, imprescindível, não poderia deixar de ser feita pelos peritos (...). Entretanto os peritos, sem observarem essas regras de perícia médico-legal, sem esses cuidados imprescindíveis, vêm afirmar absolutamente que a morte do feto deu-se por decapitação $e$ esquartejamento!! Risum tenealis! (Grifos do autor)

Depois dessas precisões, o advogado entrou no cerne da sua tese de defesa alegando em primeiro lugar a ingenuidade e a honra da acusada e, principalmente, o estado de completa privação dos sentidos e da inteligência. Esse argumento, previsto pelo Código Penal, se tornava extremamente poderoso se aplicado aos casos de crimes cometidos no puerpério. O artigo 27, parágrafo quarto do Código Penal de 1890, considerava que não eram criminosos os que se achavam "em estado de completa privação de sentidos e de inteligência" no momento em que cometeram o crime. A chamada loucura puerperal era identificada como uma das perturbações mentais passíveis de fazer desaparecer temporariamente a razão e a consciência das mulheres. Admitia-se, tanto nas teses de medicina quanto nos manuais de juristas, que o infanticídio era um dos atos cometidos por mulheres que sofriam desse mal levado às últimas conseqüências.

Contudo, Gastão Pictoria não se contentou apenas com o argumento. Ele reforçou também a idéia de que a criança já tinha nascido morta, e por isso não houvera o infanticídio. Ao dizer que os antecedentes de Gloria provavam que não seria capaz "voluntária e conscientemente de tão bárbaro crime", novamente abriu a possibilidade de que, se, por acaso, ficasse provado que ela de fato matou a criança, não teria sido de forma consciente. Ou seja, o advogado pareceu optar por manter na defesa as duas possibilidades: a primeira, que Gloria não teria cometido o crime porque a criança já nascera morta, e a segunda, que chama a atenção para que só desprovida de razão teria sido capaz de tal ato. Vejamos as palavras de Gastão Pictoria:

Exposto isso, demonstrada embora rapidamente, a imprestabilidade do exame, os autos não fornecem indícios veementes de ter a denunciada cometido o delito que lhe atribui a denúncia. A mesma confissão da acusada, ou por outra as suas declarações perante a polícia 'não constituem a confissão do delito que lhe imputam' e por aí somente se percebe ser a denunciada uma simples, quase ingênua, educada e criada sob os princípios da mais escrupulosa honra. Efetivamente a acusada, 
embora se refira ao esquartejamento, à decapitação, praticados sob o efeito de 'uma completa perturbação, ou antes, privação dos sentidos e da inteligência' devemos dizê-lo já, afirma entretanto que a criança que concebera já estava morta, quando assim procedeu. A testemunha [uma vizinha] também afirma, que assistindo às declarações da denunciada, ouviu a denunciada declarar que a criança, 'nascera morta' e, portanto, que não a matou por decapitação, ou esquartejamento.

As demais testemunhas de nada sabem, só referem-se ao fato articulado na denúncia pelo que disseram os jornais.

Os indícios veementes, necessários para a decretação da pronúncia não existem nestes autos e quando muito teríamos, meros indícios leves ou remotos.

Ao contrário, muito ao contrário, observam-se nos autos, na justificação produzida pela denunciada, contra-indícios (...) a favor da denunciada.

O passado da acusada, as suas qualidades afetivas, seu amor pelas crianças, como afirmam contestamente quatro testemunhas, todos homens muito honrados e que conhecem a acusada desde a sua mocidade e até alguns desde a sua infância, representam contra-indícios a favor da acusada, revelando a impossibilidade de serem causa poderosamente eficiente, de tornar-se ela infanticida, praticando ela voluntária e conscientemente tão bárbaro crime. (Grifos do autor)

Gloria continuou presa na Casa de Detenção até a data do julgamento, que ocorreu em 31 de março de 1909 no Tribunal do Júri, sendo presidente da sessão Antonio Angra de Oliveira. A acusação apresentou então os seguintes quesitos a serem respondidos pelos jurados:

1) A ré Gloria Lourenço da Silva, às dez e meia horas da manhã do dia 30 de julho de 1908, no Beco da Batalha $\mathrm{n}^{\circ} 12$, para evitar a desonra própria, matou, logo após o nascimento, uma criança que dera à luz, conforme se verifica do auto de exame (...)?

$2^{\circ}$ ) A ré tinha superioridade em forças sobre a vítima, de modo que esta não podia defender-se com probabilidade de repelir a ofensa?

$3^{\text {ㅇl }}$ Há circunstâncias atenuantes em favor da ré? Quais?

Já a defesa formula um único quesito: "1) O júri reconhece que a ré, quando cometeu o crime, estava em estado de completa privação de sentidos e inteligência?" 
Pela apresentação do único quesito é possível perceber que, a essa altura, o advogado privilegiava a tese da privação de sentidos e inteligência. Nota-se também que, no primeiro quesito da acusação, já estava incluída a idéia de que Gloria teria cometido o crime para evitar desonra própria. Após a deliberação, o júri, composto por doze integrantes, respondeu da seguinte forma aos quesitos:

Ao primeiro, Sim, por dez votos; a ré Glória Lourenço da Silva, às dez e meia da manhã do dia trinta de julho de mil novecentos e oito, no Beco da Batalha número doze, matou, logo após o nascimento, uma criança que dera à luz, conforme se verifica do auto de exame de fls.

Ao segundo: Sim, por dez votos; a ré tinha superioridade em forças sobre a vítima, de modo que esta não podia defender-se com probabilidade de repelir a ofensa.

Ao terceiro: Sim, por nove votos; há em favor da ré as circunstâncias atenuantes dos parágrafos primeiro e nono do art. 42 do Código Penal, não ter havido na delinqüente pleno conhecimento do mal e direta intenção de o praticar; e ter a delinqüente exemplar comportamento anterior.

Quando ao quesito da defesa: Sim, por oito votos; o júri reconhece que a ré, quando cometeu o crime, estava em estado de completa privação de sentidos e inteligência.

No dia $1^{\text {\& }}$ de abril de 1909, o juiz expediu o mandado de soltura de Gloria Lourenço da Silva. ${ }^{6}$

\section{O Discurso Jurídico e as Redefinições no Código Penal Brasileiro}

O júri reconheceu que Gloria cometera o crime, apoiado nos elementos fornecidos pela perícia e no depoimento da própria ré. Ao mesmo tempo, respondeu afirmativamente ao quesito do advogado, admitindo a privação de sentidos e inteligência. Em função dessa condição, Gloria foi absolvida, sendo este, portanto, o argumento mais importante do processo. O dado mais interessante é que em nenhum momento a tese da privação dos sentidos e inteligência foi suficientemente defendida ou demonstrada, pelo menos nos autos, de modo a sustentar a absolvição. É estranho que não conste entre as peças do processo nenhuma avaliação ou parecer médico que esclarecesse algo sobre o estado mental de Glória no momento do crime. A ausência é ainda mais significativa se consideramos que esse 
processo em particular é um exemplo precioso de acumulação de provas periciais, exames e depoimentos. A investigação contou com um trabalho minucioso dos legistas. Gloria jamais mencionou nos depoimentos qualquer referência a uma perturbação de consciência no momento do crime. Muito pelo contrário, ela foi capaz de relatar com todos os detalhes o que se passara. Além disso, o júri respondeu sim ao primeiro quesito da acusação, que menciona a defesa da honra como motivo do crime. Ora, se Gloria cometera o infanticídio para defender a honra, escondendo o nascimento assim como tinha ocultado a gravidez, deveria estar agindo conscientemente, a menos que se imagine que estivesse tão preocupada com a honra que chegara a ficar mentalmente perturbada.

Parece estranho que os jurados possam conjugar respostas positivas para o quesito da acusação e para o da defesa, principalmente se consideramos que a tese da falta de consciência tinha sido mencionada pelo advogado muito rapidamente e apenas uma vez. É claro que não sabemos o que aconteceu nos bastidores do processo. O caso se tornou público e deve ter provocado uma série de debates. E temos conhecimento que a tese da loucura puerperal como atenuante para o crime de infanticídio era considerada tanto pela justiça quanto pela medicina - especialmente a medicina legal da época. No famoso e respeitado Tratado de Medicina Legal, Agostinho J. de Souza Lima (1933) dedica várias páginas à questão da privação dos sentidos e da inteligência, nas quais cita a infecção de origem puerperal e mesmo o estado puerperal por si só como capazes de ocasionar desordens mentais e mesmo levar à loucura. ${ }^{7}$

Não é possível determinar o que se passou exatamente naquele contexto. Mas podemos nos perguntar se o comportamento dos jurados não estaria relacionado com uma dificuldade mais geral em admitir publicamente o crime do infanticídio enquanto tal, ou seja, o assassinato pela mãe do filho recém-nascido. Talvez a condenação de uma mãe por esse tipo de crime fosse uma decisão tão delicada - porque colocava em xeque o instinto materno - que era preferível admitir, mesmo sem uma demonstração convincente, a tese da privação de sentidos e inteligência. Dessa forma, pode-se conceber que Gloria tenha cometido o crime, não como uma mãe desnaturada, como quiseram o delegado e o promotor, mas como uma pobre mulher que teve sua razão perturbada pelos suplícios do parto.

Acredito que essa interpretação, possível para o caso, encontra apoio em alguns fatores que compunham o contexto da época. A valorização da 
maternidade e a pressuposição do instinto materno, que aparecem no discurso médico, seriam alguns destes aspectos. Aliado a isso, estaria a condenação pública de qualquer método de controle da reprodução ancorada na idéia de que a nação necessitava de um crescimento populacional pungente. Ao mesmo tempo, a freqüência dos argumentos que defendem a incapacidade legal das mulheres e sua fragilidade em sentido mais amplo, sempre requerendo a tutela masculina, se combina muito bem com a hipótese de que Gloria não cometera o infanticídio imbuída de motivos racionais. Ela fora vítima de uma desordem mental momentânea e merecia a compaixão, além de proteção e tutela, e não a punição. Considerar que ela de fato fosse uma criminosa cruel seria admitir que as mulheres podem matar os filhos motivadas por razões de qualquer ordem. Talvez fosse preferível deixar para trás tal possibilidade.

Se analisarmos algumas mudanças ocorridas no Código Penal, poderemos avançar nessa interpretação.

O Código Penal brasileiro de 1890 tratava do infanticídio em apenas um artigo:

Art. 298 - Matar recém-nascido, isto é, infante nos sete primeiros dias do seu nascimento, quer empregando meios diretos e ativos, quer recusando à vítima os cuidados necessários à manutenção da vida e impedir sua morte. Pena - prisão celular por seis a vinte e quatro anos.

Parágrafo único - Se o crime for perpetrado pela mãe, para ocultar a desonra própria, pena - prisão celular por três a nove anos.

Nota-se que o artigo se refere de maneira indefinida ao autor do crime, apenas especificando que a mãe pode ser a autora em um parágrafo à parte. Nesse caso, diminui-se a pena e ressalta-se o motivo da ocultação da desonra. O fato de a mãe ter cometido o crime aparece como um atenuante. Parece evidente que a mãe não comete um homicídio semelhante a qualquer outro, e esta especificidade da situação prevê uma redução do seu castigo.

Em seu Tratado de Medicina Legal, Souza Lima questiona as disposições do Código Penal de 1890. No capítulo referente ao infanticídio, afirma que esse crime é considerado menos importante e é menos severamente punido do que um homicídio. Da perspectiva do especialista, o fato é repugnante, assim como a condescendência em favor da mulher autora do assassinato do próprio filho. Ele lembra que, em se tratando do homicídio, 
a circunstância de o autor do crime ser um ascendente qualquer da vítima é considerado um agravante. No mesmo sentido, o fato de o crime ser cometido para ocultar desonra própria é também considerado um agravante para o homicídio, mas um atenuante para o infanticídio.

Souza Lima não vê razão pára que a mulher seja beneficiada porque cometeu um crime que tinha como motivação esconder a prova de relações sexuais ilícitas. Condena também a arbitrariedade da lei quanto ao prazo de sete dias para determinar o infanticídio. Lembra que a diferença de um dia pode fazer com que o crime seja punido de forma mais grave ou atenuada. O autor considera que a legislação brasileira é incongruente e não pune de forma adequada tão bárbaro crime. E confirma a raridade dos casos punidos em contraste com o número dos crimes supostamente cometidos:

Com efeito, desde que, como lente de medicina legal, me ocupo com o estudo destes assuntos e acompanho o movimento dos tribunais judiciários, desta capital, poucas vezes tenho visto levados à barra do júri, réus acusados por crime de infanticídio.

Poder-se-á acreditar seriamente que somos a este respeito um povo privilegiado, onde quase não se conhece ou não se pratica semelhante atentado?

Para responder pela negativa bastam os fatos registrados muito freqüentemente de crianças recém-nascidas abandonadas, ainda vivas ou já mortas, nas vias públicas ou em lugares ermos, em que se não podem desculpar os autores com a falta dos meios para as despesas necessárias para os enterramentos, porquanto a polícia encarrega-se deste serviço, grátis quando as pessoas são reconhecidas como indigentes.

É que, de um lado, os sinais materiais do crime de infanticídio são às vezes bem pouco acentuados para que se possam denunciar a um exame mesmo atento e meticuloso; de outro lado, com a nossa organização policial, ainda deficiente, as diligências respectivas não se têm exercitado sobre fatos desta ordem com a atividade e orientação que seria para desejar. (Souza Lima, 1933:693-694)

Souza Lima também se refere ao infanticídio considerando a circunstância da premeditação. Segundo o autor:

[a premeditação] é fora de dúvida que se verifica, constantemente, no infanticídio, seja qual for o móvel deste crime, sobretudo se se trata de uma gravidez contraída ilicitamente, de um caso de desonra, que é justamente o mais freqüente. Então, é sempre esperado o momento de dar à luz para a consumação do nefando e monstruoso atentado. 
O espírito que preside geralmente ao assassinato de um recém-nascido, e que caracteriza a figura jurídica deste crime, consiste em providenciar de modo que a criança, apenas nascida, desapareça sem ter tempo sequer de emitir o primeiro vagido, sem acusar por esta forma o seu aparecimento no mundo, onde vem ser sobrecarga, para pais miseráveis, ou, mais vezes, o corpo de delito de uma falta vergonhosa, de um labéu infamante para mães delinqüentes. (Souza Lima, 1933:694)

Parece claro que há motivos de ordem racional que levam uma mãe a cometer o infanticídio, seja de natureza financeira, seja para esconder uma gravidez condenada socialmente. No discurso de Souza Lima, a mãe pode se converter em uma delinqüente, fato impensável para aqueles que preconizavam o império do instinto materno e admitiam, como única possibilidade do crime do infanticídio pela mãe, a privação dos sentidos e da inteligência. ${ }^{8}$

A despeito da posição de Souza Lima, a associação do infanticídio com a privação da razão parece ter sido a tese mais difundida. Pelo menos é o que as disposições presentes no Código Penal de 1940 levam a crer. Neste novo Código, o infanticídio aparece sob uma nova definição: "Art. 123 - Matar, sob a influência do estado puerperal, o próprio filho, durante o parto ou logo após: pena - detenção, de dois a seis anos".

O que assistimos é a passagem do infanticídio, como um crime que poderia ser cometido por qualquer pessoa, a um ato por definição realizado exclusivamente pela mãe. E além disso, sob a influência do estado puerperal, o que significa que a mulher agiu sob o efeito de perturbações de diversas ordens decorrentes do parto. Se recorremos aos comentaristas do Código Penal de 1940, não resta dúvida sobre o significado desse artigo. Tiago Ribeiro Pontes (1976) afirma que o infanticídio é o crime da puérpera perturbada pelo estado puerperal. O autor recorre ao próprio Souza Lima e a Fernando Magalhães para explicar que, após o parto, a mulher pode sofrer perturbações que retiram temporariamente a razão, levando-a mesmo a cometer crimes como o assassinato do filho recém-nascido. ${ }^{9}$ Ou seja, não há possibilidade de infanticídio cometido por outra pessoa que não seja a mãe, que, por definição, está fora de seu estado normal. O crime é cometido por alguém que não estava plenamente consciente. E, apesar da pena prevista, parece bastante difícil a condenação de um indivíduo que não pode ser totalmente responsabilizado pelo ato que cometeu, já que não estava no seu juízo perfeito.

É bom lembrar que o Código Penal de 1940, a respeito da isenção de pena, dispõe o seguinte: "Art. 22 - É isento de pena o agente que: por 
doença mental (...) era, ao tempo da ação ou da omissão, inteiramente incapaz de entender o caráter criminoso do fato ou de determinar-se de acordo com esse entendimento".

Recorrendo à Revista Forense e à Revista dos Tribunais - duas importantes revistas de jurisprudência -, que compilam casos e artigos de doutrina da primeira metade do século $\mathrm{XX}$, pode-se perceber que a definição de infanticídio prevista no Código de 1940 causou muitas polêmicas. Durante toda a década de 1940, inúmeros artigos sobre o tema foram publicados por juízes, promotores, advogados e médicos legistas de renome. Já em 1941, o advogado C. J. de Assis Ribeiro se pronunciava contra o que parecia ser a corrente predominante, que considerava o infanticídio como um delito excepcional, definido pelas perturbações da mãe associadas ao parto e ao puerpério. Chamava a atenção para o fato de que raramente o parto dava origem a esse tipo de perturbações (Revista Forense, 86:707-708, 1941).

Em 1942, A. F. de Almeida Junior, professor de medicina legal da Faculdade de Direito de São Paulo, publicou um artigo que se tornaria famoso, tratando do infanticídio em consonância com o novo Código Penal, ${ }^{10} \mathrm{em}$ que afirma que perturbações de três ordens podem afetar a mulher no momento do parto e do puerpério. No primeiro grupo estariam as psicoses francas, ocasionadas pelo puerpério ou em concomitância com ele, como as síndromes confusionais de origem tóxica ou infectuosa, os acessos de mania ou de melancolia, os fenômenos esquizofrênicos etc. ${ }^{11}$ Mas a mãe infanticida incluída nesse grupo já estaria isenta de culpa com base no artigo 22 do Código, que trata daqueles incapazes de entender o caráter criminoso dos seus atos. No segundo grupo estariam aquelas que sofrem de semi-alienação mental, como as perversas instintivas, as histéricas e as débeis mentais. Também nesse caso, o mais correto seria a aplicação do artigo 22. Ao terceiro grupo é que se aplicaria o artigo 123. Nele, estariam os casos em que "a mulher, mentalmente sã, mas abalada pela dor física do parto, fatigada, sacudida pela emoção, vem a sofrer obnubilação da consciência, perturbação dos impulsos volitivos, chegando por isso a matar o próprio filho, durante o parto ou logo após" (Revista Forense, 91:40, 1941). Esse abalo seria ainda maior nos casos em que, ao lado da emoção do fato fisiológico, se associasse a vergonha e o receio de sanções pela família e pela sociedade em se tratando de filho ilegítimo. O trecho seguinte, resumindo as conclusões do autor, seria utilizado por muitos magistrados no pronunciamento de suas sentenças: “A nosso ver, a 'influência do estado 
puerperal', agora prevista pela lei, é o efeito normal e corriqueiro de qualquer parto; e, dada a sua grande freqüência, deverá ser admitida sem maior dificuldade. Presente a causa da honra, então, parece-nos, deva ser afastada qualquer dúvida" (Revista Forense, 91:40, 1941).

$\mathrm{O}$ artigo do promotor público de Porto Alegre, Henrique Fonseca de Araújo, defende que a única razão para que se dê um tratamento especial no caso do infanticídio é a defesa da honra da mulher. Segundo o autor, não se pode colocar em pé de igualdade a mãe que mata o próprio filho, fruto de uma união legal, por puro egoísmo ou para se furtar dos encargos da maternidade, e aquela que mata para ocultar a sua desonra, decorrente de um filho concebido fora dos laços conjugais. ${ }^{12}$ Dessa forma, o autor entra em conflito direto com a nova lei. Critica severamente o artigo 123, na medida em que supõe que toda mulher que matar o filho durante ou logo após o parto, e portanto sob a influência do estado puerperal, será beneficiada. Araújo admite que na "Exposição de Motivos", que acompanhou o projeto de lei, elaborada pelo ministro Francisco Campos, tenta-se esclarecer melhor o texto. ${ }^{13}$ Mas, na prática, seriam tantas as dificuldades para provar as perturbações causadas pelo puerpério, que a jurisprudência acabaria admitindo a inimputabilidade da parturiente, principalmente se o crime continuasse a ser julgado pelo júri popular, composto de leigos (Revista Forense, 89:289-292, 1942).

O autor lamenta que a nova lei tenha se baseado no 'princípio ascético', que se recusa a admitir que um crime pudesse ser desculpado por um pecado anterior. Do seu ponto de vista, deveria continuar prevalecendo, como era no Código de 1890, o 'princípio político', que vê no móvel do crime (a preservação da honra) uma razão de menor gravidade. Aplicado ao infanticídio, esse último princípio levaria à consideração da mulher que agiu pensando na sua honra como uma delinqüente menos perigosa, diferente do homicida vulgar. A mulher que comete tal crime, em parte o faz movida por um sentimento de respeito aos postulados morais que regem a sociedade na qual vive (Revista Forense, 89:291-292, 1942).

Leonídio Ribeiro também se dedicou a criticar as novas disposições legais acerca do infanticídio. Chamou a atenção para a infelicidade do texto da lei, que não pressupõe explicitamente a existência de uma relação causal entre o estado puerperal e o crime cometido. Além disso, salientou as dificuldades enfrentadas pelos peritos, desde a definição exata do período do puerpério, discutida entre os próprios mestres da obstetrícia, até a 
averiguação dos possíveis distúrbios psíquicos da acusada. O médico legista também reclamou que entre os quesitos elaborados de forma a orientar as investigações não constava nada referente ao estado psíquico da mãe ${ }^{14}$ (Revista Forense, 94:381-384, 1943). Ou seja, pressupunha-se que o infanticídio era praticado pela mulher em um estado de perturbação mental e nada era previsto no sentido de averiguar essa condição. Assim, parece reforçada a idéia de que a loucura ou perturbação eram intrínsecas ao estado puerperal, não precisando ser investigadas, uma vez que ficasse provado que o crime tinha sido cometido pela mãe da criança no momento do parto ou logo após.

Na jurisprudência criminal dos anos que se seguiram à colocação em prática do novo Código, é possível notar as dificuldades dos juízes no entendimento e aplicação da lei relativa ao infanticídio, bem como a variação das decisões. O acórdão relativo ao processo de Maria de Jesus (em Diamantina) confirma a condenação de infanticídio, definindo o crime sob a inspiração de Almeida Junior e destacando que a influência do estado puerperal é o efeito normal e corriqueiro de qualquer parto (Revista Forense, 96:715, 1943). No caso envolvendo Balbina Novack (em Porto Alegre), mais uma vez a tese de Almeida Junior iria prevalecer, mas o acórdão põe em relevo também o argumento da ocultação de desonra (Revista Forense, 109:223-224, 1946). Já na acusação feita a Otília Soares Rodrigues (em Natal), o juiz pressupõe que a inibição transitória da consciência é uma exceção no puerpério, sendo regra geral a normalidade e cabendo à defesa o ônus de provar essa exceção (Revista Forense, 114:236-237, 1947). No acórdão relativo ao caso de Maria Faustina (também em Natal), os juízes defendem que não é à delinqüente - puérpera e, segundo a lei, presumidamente perturbada em seu psiquismo - que incumbe o dever de trazer a juízo a prova de que o crime ocorreu efetivamente em conseqüência do estado puerperal (Revista Forense, 117:578-582, 1948). O resultado é que todas as mulheres nesse estado, a princípio, teriam de contar com o benefício da dúvida sobre sua responsabilidade legal. E no processo contra Maria Francisca da Cruz Teixeira (em Belo Horizonte), a tese da consciência obnubilada é admitida pelos juízes no acórdão referente ao caso, mas sua interpretação fica subsumida à hipótese da vergonha e desonra pelo fato da criança ser ilegítima (Revista Forense, 119:258-269, 1948).

O que se destaca quando consideramos os processos analisados, ainda sob a vigência do Código Penal de 1890, e estas informações relativas ao teor e à aplicação do artigo 123 do Código de 1940, é a discussão em 
torno da excepcionalidade do crime de infanticídio, seja pelas perturbações inerentes ao estado puerperal, seja prevalecendo a tese da defesa da honra. É importante salientar que alguns magistrados chegaram mesmo a aproximar estas situações, a partir de uma certa 'psicologização' da honra. Na sentença de Otília Soares Rodriges, menciona-se a falta de consciência da infanticida decorrente de um 'motivo psicológico' - definição aplicada pelos juízes às perturbações associadas com a vergonha de expor um filho ilegítimo - ou de um 'fator fisio-psíquico' - que se refere às perturbações intrínsecas ao estado puerperal (Revista Forense, 114:236-237, 1947). Em qualquer das duas hipóteses, o infanticídio não pode ser considerado como um crime comum. Há algo de misterioso e indefinido na sua natureza, o que fica evidente nos debates entre os magistrados. Para além de princípios de doutrina e disputas entre escolas que, evidentemente, também estão em cena, talvez se possa evocar um outro argumento.

\section{A Singularidade do Infanticídio}

Ao tratar da associação entre crime e loucura ${ }^{15}$ na passagem do século, Sergio Carrara (1987) apresenta aquilo que pode se converter em uma explicação para esta questão. $O$ autor faz uma primeira referência importante a respeito da convivência de duas concepções, uma moral e axiomática, e outra objetiva e objetivante, como dois códigos incompatíveis de compreensão das ações humanas e da responsabilidade individual. E fazendo menção a casos famosos, afirma que os motivos de um crime considerado particularmente hediondo podem ser moralmente tão inaceitáveis que a razão se recusa a compreendê-los. É a partir dessa brecha que a medicina passa gradativamente a ser chamada a dar explicações e os alienistas passam a freqüentar os tribunais. Não seriam motivos de ordem racional que explicariam as atitudes dos criminosos, mas as desordens mentais. Os crimes que podem ser entendidos como ordinários, como furto, estelionato, estupro, consistiriam em subversões dos meios socialmente dados para a consecução de fins considerados legítimos e desejáveis, como a riqueza, posição social ou prazer sexual. Esses podiam ser avaliados pelos juristas e magistrados. Aqueles que fogem a essa regra têm de ser observados de uma outra forma, contando com a ajuda dos médicos. De acordo com Carrara (1987:83-84):

Os crimes que clamam pelas considerações médicas parecem possuir uma outra estrutura, pois dizem respeito, primordialmente, à subver- 
são escandalosa de valores tão básicos que se pretende estejam enraizados na própria natureza humana - amor filial, amor materno ou piedade frente à dor e ao sofrimento humano. Dessa maneira, não é surpreendente que tais subversões, tão radicais e escandalosas, coloquem em questão a própria 'humanidade' de parricidas, infanticidas, assassinos cruéis, sendo melhor interpretadas no contexto de selvagerias da natureza, mais afeitas, portanto, à abordagem das 'ciências biológicas ou naturais'. (Grifos do autor) $)^{16}$

Nesse sentido, a natureza desumana do infanticídio também estaria em jogo na alteração do Código Penal, que era, por sua vez, um reflexo do que acontecia nos processos ocorridos até então, como foi o caso da absolvição de Gloria Lourenço da Silva. Ou seja, o assassinato de um filho pela própria mãe tinha a tendência de ser presumido como um ato cometido fora do juízo perfeito. O fato de o Código de 1940 definir o infanticídio desta forma pode estar relacionado com uma dificuldade em admitir a atitude de uma mãe que mata o próprio filho. Para além da possibilidade efetiva de uma perturbação mental temporária decorrente do fato, a questão tratada aqui é a definição do infanticídio somente dentro desse quadro e a absolvição de Gloria sem uma demonstração mais convincente, pelo menos considerando o que consta nos autos, da manifestação de tal perturbação. Talvez não seja 'ir longe demais' pensar que era preferível comprar um tanto apressadamente a hipótese da associação entre infanticídio e perturbação mental no puerpério do que investigar a fundo as razões do crime. É possível que os motivos fossem racionais em demasia, evidenciando publicamente o desejo e a atitude dramática de mulheres que não podiam ou não queriam ter filhos.

A natureza excepcional do crime do infanticídio aparece no artigo do juiz de direito Herotides da Silva Lima, publicado ainda em 1929. A intenção do juiz é denunciar a 'brandura' com que são punidas as infanticidas. Mas, ao explicitar seu argumento, o autor deixa clara a percepção dos juristas a respeito da qualidade antinatural e anti-social do crime. Lima defende que o infanticídio, ao contrário de ter uma pena mais leve em relação ao homicídio comum, deveria implicar uma sansão mais pesada, já que é um fato que deve ser muito mais temido pela sociedade. Segundo ele, nunca a sociedade encontrará explicação para esse crime, que foge aos padrões normais dos outros delitos:

O matador de um recém-nascido revela uma temibilidade maior que o assassino vulgar. Maiores são a perversidade e a covardia; mais 
lancinante a dor da familia, golpeada fundamente em toda a variada escala de sentimentos delicados que a criança desperta e conserva no ambiente doméstico; maior o abalo da sociedade, que não encontrará jamais explicação para a brutalidade do ataque contra uma criatura incapaz de fazer e compreender o mal, desprovida de força, de agilidade ou destreza, para se livrar aos ataques; um fraco, inerme; inocente, para quem a piedade humana está sempre voltada. (Revista dos Tribunais, 69:259, 1929)

Lima destaca que a natureza cruel do crime se torna ainda mais grave quando a mãe é a envolvida, já que a ela caberia, em primeiro lugar, a proteção e o cuidado do filho. Para o autor, a maternidade consiste na abnegação, no sacrifício e na renúncia. Se esses sentimentos ou atitudes estão ausentes, a conseqüência imediata, e de extrema gravidade para a sociedade, é o aniquilamento da família. Dessa forma, Lima permite entender como a figura da mãe infanticida era percebida como um perigo social, porque representava um rompimento com os valores e o comportamento tradicionalmente associados à mulher e à maternidade. Isso fica ainda mais claro quando o autor propõe que a solução para a diminuição da prática do infanticídio está na educação da mulher para a maternidade. A emancipação feminina aparece no argumento de forma ambígua, frente a esta necessidade imperiosa do cuidado com os filhos. O autor diz: "Eduquese a mulher, que tanta praça faz hoje da sua independência, desembaraço e igualdade; proteja-se a inocência contra os botes da crueldade" (Revista dos Tribunais, 69:261, 1929).

É importante citar ainda que Lima contextualiza a condenação ao infanticídio dentro de um projeto de maior proteção à infância pelo Estado. Afirma que a garantia dos direitos do indivíduo tem sido dilatada para as crianças, destacando medidas radicais de proteção, especialmente à primeira idade, punindo os pais ou responsáveis que não cumprem os seus deveres. Acrescenta que no direito moderno, o pátrio poder está organizado de modo a atender aos interesses sociais e da criança. O Estado, nesse sentido, teria mais direito do que os próprios pais. Por fim, diz que: "Nós nos inscrevemos entre os povos cultos, cuidando de amparar os pequeninos entes, cuja vida e formação interessam mais ao País que à família" (Revista dos Tribunais, 69:260, 1929).

Um último comentário poderia ser feito, a partir do estudo de Richard Lalou (1986), sobre o infanticídio nos tribunais franceses entre 1825 e 1910. O autor tenta demonstrar, a partir de estatísticas, a extensão desse 
fenômeno, que, segundo ele, era comum em toda a Europa e que começou a diminuir no fim do século XIX. Destaca que 70\% dos acusados, na sua grande maioria jovens mulheres solteiras, não eram julgados por falta de provas. Além disso, a pena de morte prevista era considerada pelos próprios magistrados como excessivamente pesada. E assim como no Brasil, invocava-se em favor da mulher a tese da não responsabilidade ou da loucura puerperal. Lalou (1986:194) argumenta que a indulgência freqüente pode ser relacionada à dificuldade da sociedade em lidar com um crime de tal ordem: "Invocar a loucura quando uma mulher mata sua criança parece assaz sintomático da atitude da sociedade a respeito do infanticídio. $O$ assassinato de uma criança recém-nascida é um ato que não pode pertencer à razão, tendo que ser justificado pela demência doentia da mãe que pariu" (Tradução minha).

Acrescenta que a honra também é constantemente evocada nas defesas, o que faz sentido quando se constata que a maioria das acusadas eram solteiras e, portanto, mãe de filhos ilegítimos. O júri era indulgente com a acusada porque ela, ao cometer o infanticídio, teria reconhecido as normas da sociedade que infringiu ao ter uma relação sexual ilícita. A acusada tomava consciência do ato cometido, ao transgredir o interdito das relações sexuais fora do casamento, e tentava reparar o erro suprimindo a prova. Segundo o autor, as acusações contra infanticidas teriam diminuído a partir da década de 1870 porque a sociedade teria começado a tolerar melhor a presença de mães solteiras e filhos ilegítimos, em um contexto onde a rápida industrialização tinha favorecido a dissociação do núcleo familiar nas grandes cidades. ${ }^{17}$ Além disso, um maior acesso aos meios contraceptivos teria ajudado as mulheres a administrar melhor a sua fecundidade antes de chegar ao extremo do infanticídio.

Lalou termina dizendo que há também, progressivamente, o desenvolvimento de um sentimento específico em relação à infância. A criança que nasce adquire uma importância cada vez maior e as mães passam a hesitar mais em suprimir a nova vida. ${ }^{18}$ Nesse sentido, o desaparecimento progressivo do infanticídio estaria relacionado com uma dupla mudança nas mentalidades: uma mudança de atitude da sociedade em relação à mãe solteira e ao filho ilegítimo, e uma mudança de sentimento da mãe em relação à criança. ${ }^{19}$ De qualquer forma, a conclusão do autor é que também na França o que marca o tratamento do infanticídio é "uma repressão hesitante que tende a marginalizar um crime embaraçante" (Lalou, 1986:186. Tradução minha). 
É necessário ainda lembrar, retomando as colocações do capítulo anterior, que, também no caso de Gloria Lourenço da Silva, parece haver um hiato entre a maneira que ela narra os fatos e as interpretações do delegado, do advogado e dos jurados. Gloria conta a sua história entremeada de momentos de conturbação pessoal, como o namoro em Portugal, a vinda recente para o Brasil, a gravidez escondida, o parto e o ato de esquartejamento da criança. $O$ delegado traduz isso em termos da imagem de uma mãe desnaturada e desumana. O advogado evoca a privação de sentidos e da inteligência, argumento aceito pelos jurados. Esse argumento, contudo, tinha sido muito pouco explorado e parece não se coadunar com os depoimentos de Gloria. Talvez a história desse processo fique mais clara se admitirmos que, enquanto Gloria relatava sua história a partir de um determinado conjunto de valores e representações sociais, o advogado, os jurados e outros personagens da cena jurídico-policial atuavam orientados por concepções distintas. Na leitura que os últimos fizeram do caso, a hipótese de que ela cometeu o infanticídio pela condição de privação dos sentidos e da inteligência, decorrente do parto e do medo de tornar pública a sua relação ilícita, é o que se apresenta como mais provável. Mas, no relato de Gloria, a idéia da perda de razão não aparece. A idéia da privação de sentidos e inteligência parece ser unicamente uma teoria vinda de um outro mundo, que não é o de Gloria.

Deve-se salientar nesta discussão em torno do infanticídio que não há somente um único modo de entender os resultados dos casos julgados, como o de Gloria Lourenço da Silva, e mesmo as alterações no Código Penal Brasileiro, principalmente porque não é possível controlar ou ter acesso a todos os fatores envolvidos. Contudo, não se pode deixar de notar que um aspecto fundamental do problema é a dificuldade em lidar com o crime da mãe que mata o próprio filho, considerado tão excepcional quando se pressupõe o amor materno como uma característica essencial da natureza feminina. Isto se torna ainda mais evidente considerando o contexto das primeiras décadas do século XX, quando a criança e a maternidade passaram a ocupar um lugar de destaque na propaganda e nos programas do Estado nacional. 


\section{Notas}

uisando revistas de jurisprudência, encontrei um caso semelhante. Trata-se do processo que absolveu Anna de Souza (em Belo Horizonte) da acusação de infanticídio, com base na tese da completa perturbação dos sentidos e da inteligência. Dessa vez, o promotor recorreu e um acórdão decidiu pela anulação do julgamento (Revista Forense, 65:203-204, 1935)

7 Souza Lima (1933:434) ainda reforça a relação entre alterações no aparelho genital e desordens mentais fazendo menção a um caso que suponho ser o processo movido contra o médico Abel Parente em 1901: "Os excessos venéreos, as alterações que têm sua sede no aparelho genital podem determinar direta ou indiretamente desordens mentais; num caso já citado, a propósito de responsabilidade profissional, elas foram provocadas por aplicações cervico-uterinas tendentes à esterilização da paciente".

8 É notável que Souza Lima tenha tratado do estado puerperal como causador de loucura, no capítulo referente à privação dos sentidos e da inteligência, ou seja, entre as circunstâncias atenuantes. Suponho que quando estava tratando das circunstâncias atenuantes, o autor estava preocupado em apresentar as possibilidades consideradas pelos juristas brasileiros. Já no caso de sua análise do Código em relação ao infanticídio, o objetivo é mostrar as falhas da legislação, desenvolvendo para tanto argumentos mais pessoais.

9 As obras citadas são o Tratado de Medicina Legal, de Souza Lima (1933) e Obstetrícia Forense, de Magalhães (1933).

o No mesmo artigo, o autor trata também do aborto e diz que, quanto ao aborto criminoso, o Código Penal de 1940 não havia introduzido grandes modificações. Comenta também que o 'aborto eugênico', proposto por médicos alemães e ingleses, não foi considerado na nova lei, o que merece a seguinte explicação do autor: "A Eugenia não está, por ora, suficientemente esclarecida para que possa servir de guia seguro nas indicações abortivas; e, mesmo que o estivesse, suponho que dificilmente modificaria a atual linha de conduta, que consiste em apoiar-se, para os seus propósitos, principalmente nos meios eugênicos positivos, ou seja, no estímulo à reprodução dos elementos biologicamente bem dotados" (Revista Forense, 91:45, 1941. Grifo do autor). Sobre a repercussão das novidades em torno do aborto no Código Penal de 1940, ver também o artigo de Alaim de Almeida Carneiro (Revista Forense, 89:292-295, 1942).

1 Almeida Junior (Revista Forense, 91:39, 1941) ressalta que não se trata da loucura puerperal, tal como definida pelo psiquiatra francês Marcé. Para este autor, a loucura ou psicose puerperal teria como única manifestação o assassinato do próprio filho. 
1 Considerando o contexto exposto a partir dos textos médicos que atestam uma valorização da maternidade - para as mulheres saudáveis e cumpridoras das regras sociais - não é de se espantar que as mães que cometem infanticídio contra os filhos legitimos sejam mais severamente condenadas que as outras.

13 De acordo com Francisco Campos: “O infanticídio é considerado um delictum exceptum quando praticado pela parturiente sob a influência do estado puerperal. Esta cláusula, como é óbvio, não quer significar que o puerpério acarrete sempre uma perturbação psíquica: é preciso que fique averiguado ter esta realmente sobrevindo em conseqüência daquele, de modo a diminuir a capacidade de entendimento ou de auto-inibição da parturiente. Fora daí, não há por que distinguir entre infanticídio e homicídio" (Revista Forense, 89:290, 1942. Grifos do autor).

4 Os quesitos eram apenas os seguintes: “19) se houve morte; $2^{2}$ ) se a morte foi ocasionada durante o parto; $3^{\circ}$ ) qual a causa da morte?; $4^{\circ}$ ) qual o instrumento que produziu a morte?; $5^{2}$ ) se foi produzida por meio de veneno, fogo, explosivo, asfixia ou tortura, ou por meio insidioso e cruel" (Revista Forense, 94:383, 1943).

15 Sobre o alcance que o conceito de loucura pode tomar no contexto dos processos criminais já nas primeiras décadas do século XX, ver a análise de Fry (1982) sobre o caso de Febrônio Índio do Brasil.

16 Carrara (1987) prossegue mostrando como a teoria da degeneração foi importante para que se constituísse uma reflexão médica específica sobre o crime que o transformava em patologia. Segundo o novo entendimento dos médicos, as transgressões partiam de indivíduos cuja situação doentia parecia ser um estado permanente, inato e constitutivo. Quanto às conseqüências desse tipo de concepção no direito penal, considerando a questão da violação voluntária das regras sociais em contraste com a idéia de uma essência criminosa, ver Fry \& Carrara (1986).

17 Lalou (1986) e também Bardet \& Dupâquier (1986) insistem que o infanticídio era um crime mais comum no meio rural, enquanto o aborto seria mais praticado na área urbana.

i Apesar dessa afirmação, Lalou (1986) é bastante cuidadoso ao dizer que não há uma evolução linear da percepção da infância.

19 Lebrun (1986:255) relaciona uma nova percepção da criança às práticas contraceptivas: "as crianças tornam-se objeto de um verdadeiro investimento, ao mesmo tempo sentimental e material. À imprevidência em matéria de procriação se sucede um malthusianismo calculador e quase ascético, já que ele responde ao desejo de assegurar uma sorte melhor a um número menor de crianças, visão bastante terrena, ao contrário da concepção cristã, e que caminha junto com uma descristianização da sociedade" (Tradução minha). 